\title{
SISTEM PAKAR GANGGUAN ANSIETAS PERPISAHAN MASA KANAK DAN REMAJA MENGGUNAKAN CERTAINTY FACTOR BERBASIS WEB
}

\author{
Keken Wilujeung ${ }^{1}$, Yessy Yanitasari ${ }^{2}$, Supriyadi ${ }^{3}$, Abdul Gowi $^{4}$ \\ 1'kekenwilujeng6@gmail.com, ${ }^{2}$ yessy.yanitasari@gmail.com, 3fnfcreator@stmik-kharisma.ac.id, \\ ${ }^{4}$ abdul.gowi@gmail.com \\ ${ }^{1,2,3}$ Teknik Informatika, STMIK Kharisma Karawang, ${ }^{4}$ Keperawatan, STIKes Kharisma Karawang
}

\begin{abstract}
Abstrak
Sistem Pakar merupakan sistem komputer yang berbasis pengetahuan yang terpadu di dalam suatu sistem informasi, sehingga memiliki kemampuan untuk menyelesaikan masalah dalam bidang tertentu sebagaimana layaknya seorang pakar. Sistem pakar bertujuan untuk memudahkan pengguna agar mengetahui solusi masalah yang biasanya dipecahkan oleh pakar. Salah satu contoh kasusnya adalah gangguan ansietas perpisahan masa kanak dan remaja. Gangguan ansietas perpisahan masa kanak dan remaja merupakan kecemasan dan kekhawatiran yang tidak realistik pada anak tentang apa yang akan terjadi bila ia berpisah dengan orang-orang yang berperan penting dalam hidupnya, misalnya orang tua. Berdasarkan prevalensi nasional, tingkat gangguan ansietas cukup tinggi serta masyarakat belum mengetahui jenis gangguan ini. Sistem pakar yang dibangun memiliki keluaran sistem berupa solusi teknik keperawatan seperti cara terapi yang bisa dilakukan oleh keluarga Perancangan aplikasi ini berbasis web dengan menggunakan mesin inferensi Certainty Factor yang menggabungkan nilai keyakinan pakar dan pengguna serta metode pengembangan sistem yang digunakan berbasis Object Oriented.
\end{abstract}

Kata kunci : Certainty factor, gangguan ansietas perpisahan, keperawatan jiwa, Sistem pakar.

\section{Pendahuluan}

Perkembangan penggunaan komputer yang semakin meluas telah memacu industri komputer untuk mengembangkan generasi komputer yang semakin canggih. Perkembangan tersebut dimulai sejak penelitian dan pengembangan di bidang mesin kecerdasan buatan dan penelitian dengan konsep "array processor" [1]. Salah satu perkembangan tersebut adalah sistem pakar yang merupakan salah satu cabang dari kecerdasan buatan. Sistem pakar yaitu sistem komputer yang berbasis pada pengetahuan yang terpadu di dalam suatu sistem informasi dasar yang ada, sehingga memiliki kemampuan untuk menyelesaikan masalah dalam bidang tertentu secara cerdas dan efektif, sebagaimana layaknya seorang pakar [1]. Pembangunan sistem pakar bertujuan untuk memudahkan pengguna untuk mengetahui solusi masalah yang biasanya dipecahkan oleh pakar dibidang tertentu. Salah satu contoh kasusnya adalah gangguan ansietas perpisahan masa kanak dan remaja. Gangguan ansietas perpisahan adalah salah satu gangguan emosional yang biasanya terjadi pada masa kanak dan remaja. Masalah kesehatan jiwa perlu menjadi fokus utama tiap upaya peningkatan sumber daya manusia, mengingat anak dan remaja merupakan generasi yang perlu disiapkan sebagai kekuatan bangsa Indonesia. Jika ditinjau dari proporsi penduduk, $40 \%$ dari total populasi terdiri atas anak dan remaja berusia 0-16 tahun, $13 \%$ dari jumlah populasi adalah anak berusia dibawah 5 tahun. 7-14\% dari populasi anak dan remaja mengalami gangguan kesehatan jiwa, termasuk dengan anak tunagrahita, gangguan perilaku, kesulitan belajar dan hiperaktif Sebanyak 13,5 $\%$ balita merupakan kelompok anak berisiko tinggi mengalami gangguan perkembangan, sementara $11,7 \%$ anak prasekolah berisiko mengalami gangguan perilaku [2]. Prevalensi nasional gangguan mental emosional pada penduduk yang berumur $\geq 15$ tahun adalah $11,6 \%$ [3] dan $6,0 \%$ (37.728 orang dari subyek yang dianalisis) [4]. Berdasarkan data tersebut, masyarakat belum mengetahui jenis gangguan ini, mahalnya untuk melakukan konsultasi ke psikiater serta belum adanya penelitian sistem pakar untuk mengidentifikasi jenis gangguan ansietas. Ansietas suatu gangguan kecemasan dan kekhawatiran yang tidak realistik pada anak tentang apa yang terjadi bila ia berpisah dengan orangorang yang berperan penting dalam hidupnya, misalnya orang tua. Gangguan rasa kecemasan akan perpisahan dapat mengganggu dan memperlambat perkembangan sosial karena ia tidak mengembangkan indepedensi atau belajar bergaul dengan teman sebayanya [5]. Pembangunan sistem pakar menggunakan mesin inferensi certainty factor. Dalam aplikasi sistem pakar terdapat suatu metode untuk menyelesaikan masalah ketidakpastian data, salah satu metode yang dapat digunakan adalah faktor kepastian [6]. Karena Sistem pakar harus mampu bekerja dalam ketidakpastian [7]. Secara konsep, Certainty Factor merupakan salah satu teknik yang digunakan 


\section{ILKOM Jurnal Ilmiah Volume 9 Nomor 1 April 2017}

untuk mengatasi ketidakpastian dalam pengambilan keputusan. Certainty Factor dapat terjadi dengan berbagai kondisi diantara kondisi yang terjadi adalah terdapat beberapa anteseden (dalam rule yang berbeda) [8]. Tahapan proses perhitungan presentasi certainty factor yaitu tentukan rule, pisahkan multiple rule menjadi single rule, hitung nilai certainty factor pakar dengan nilai mb dan md disetiap gejala, hitung nilai certainty factor setiap rule, hitung nilai kombinasi certainty factor [9]. Maka perlu adanya sistem yang membantu masyakarat umum untuk lebih mengetahui informasi secara dini bagaimana cara merawat jika ada salah satu anggota keluarga yang mengalami gangguan ansietas perpisahan. Sistem yang akan dibuat adalah sistem pakar yang bersifat statis dengan keluaran sistem berupa solusi teknik asuhan keperawatan dengan batasan usia untuk kanak-kanak adalah masa usia sekolah 6 tahun sampai remaja 18 tahun. Maka penulis menuangkannya dalam skripsi berjudul "Sistem Pakar Gangguan Ansietas Perpisahan Masa Kanak dan Remaja Menggunakan Certainty Factor Berbasis Web" menggunakan metode pengembangan System Development Life Cycle (SDLC) Waterfall [10].

\section{Metode Penelitian}

\subsection{Metode SDLC Waterfall}

Metode penelitian yang digunakan untuk membangun sistem adalah metode SDLC Waterfall [10] yang terdiri dari lima tahapan.

2.2.1 Project Planning Phase

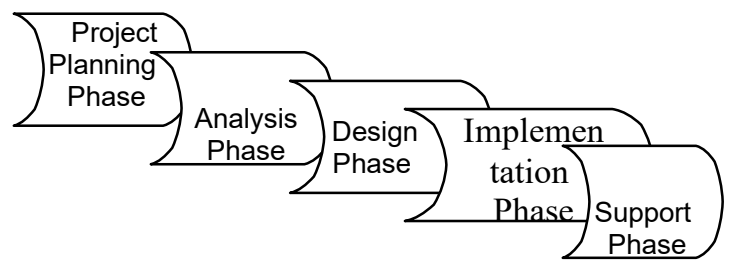

Gambar 1. SDLC Waterfall

Berikut ini adalah project planning phase.

Tabel 1. Rincian Project Planning Phase

\begin{tabular}{|c|c|}
\hline Tahapan & Deskripsi \\
\hline 1. Identifikasi Masalah & $\begin{array}{l}\text { 1. Bagaimana proses mengidentifikasi gangguan ansietas } \\
\text { perpisahan masa kanak dan remaja? } \\
\text { 2. Bagaimana membangun sistem pakar menggunakan mesin } \\
\text { inferensi certainty factor dan metode SDLC waterfall untuk } \\
\text { gangguan ansietas perpisahan masa kanak dan remaja? }\end{array}$ \\
\hline 2. Pengumpulan Data & $\begin{array}{l}\text { Teknik melakukan pengumpulan data meliputi Wawancara } \\
\text { dan Studi literatur }\end{array}$ \\
\hline 3. Analisis Teori & $\begin{array}{l}\text { 1. Analisis metode sistem pakar dan metode pengembangan } \\
\text { sistem SDLC Waterfall. } \\
\text { 2. Analisis gangguan ansietas pada masa kanak dan remaja. }\end{array}$ \\
\hline 4. Pembuatan Jadwal & $\begin{array}{l}\text { Membuat jadwal perencanaan pelaksanaan sistem pakar } \\
\text { identifikasi gangguan ansietas perpisahan masa kanak dan } \\
\text { remaja menggunakan metode certainty factor berbasis web. }\end{array}$ \\
\hline 5. Mencari Solusi & $\begin{array}{l}\text { Bagaimana membangun sisem pakar menggunakan mesin } \\
\text { inferensi certainty factor dan metode metode SDLC waterfall } \\
\text { untuk gangguan ansietas perpisahan masa kanak dan } \\
\text { remaja. }\end{array}$ \\
\hline 6. Mendefinisikan Kebutuhan & $\begin{array}{l}\text { Penelitian menggunakan perangkat keras dan perangkat } \\
\text { lunak. }\end{array}$ \\
\hline
\end{tabular}

2.2.2 Analysis Phase

1. Analisis Teori

(a) Analisis gangguan ansietas perpisahan 
ILKOM Jurnal IImiah Volume 9 Nomor 1 April 2017

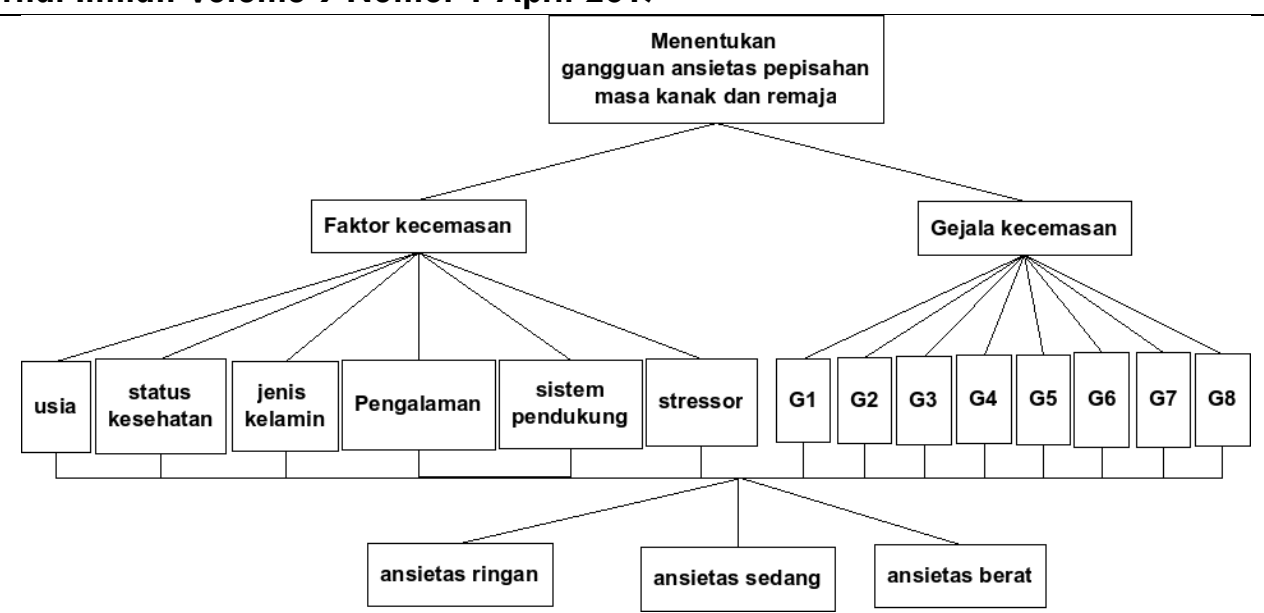

Gambar 2. Analisis gangguan ansietas perpisahan

(b) Analisis Tahapan pembentukan sistem pakar

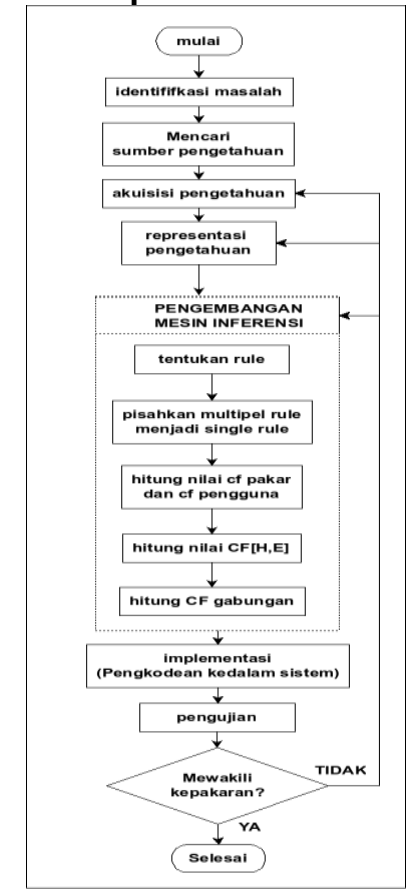

Gambar 3. Tahapan Pembentukan sistem pakar

2. Analisis Sistem

1. System Activities (Actor Description and Use Case Description, Use Case Diagram, Scenario Use Case).

2. Class Diagram (Class Definition, Class Relation).

3. Object Interaction (Sequence Diagram).

4. Object Behavior (Activity Diagram).

\section{Design Phase}

1. Desain Antarmuka

2. Desain Database

\section{Implementation Phase}

1. Instalasi Sistem

Menjelaskan tahapan-tahapan mengenai proses instalasi aplikasi.

2. Pelatihan Prosedural

Pelatihan tata cara penggunaan aplikasi yang telah diinstal.

3. Pengujian Terhadap Sistem

a.Pengujian white box: Dilakukan pada syntax dan algoritme aplikasi.

b.Pengujian black box: Dilakukan oleh pengguna untuk menguji setiap fungsi didalam aplikasi.

\subsubsection{Support Phase}


ILKOM Jurnal IImiah Volume 9 Nomor 1 April 2017

Melakukan uji kelayakan sistem serta melakukan pembaruan dan memelihara sistem setelah dijalankan.

\section{Hasil dan Pembahasan}

\subsection{Project Planning Phase}

Tahapan Project Planning Phase menghasilkan rincian setiap aktivitas yang dilakukan pada metode penelitian.

Tabel 2. Hasil Project Planning Phase

\begin{tabular}{l} 
No Tahapan \\
\hline 1. Identifikasi Masalah \\
2. Pengumpulan Data \\
3. Menganalisis Teori \\
4. Pembuatan Jadwal \\
5. Mencari Solusi \\
6. Mendefinisikan Kebutuhan
\end{tabular}

\subsection{Analysis Phase}

\section{Analisis Teori}

\section{(a) Analisis gangguan ansietas perpisahan}

Hasil dari faktor dan gejala ansietas akan menghasilkan tingkat ansietas masing-masing memiliki skala $<8$ tidak ada ansietas, 8-15 Ansietas ringan, 16 - 24 Ansietas sedang dan 25-32 Ansietas berat.

(b) Analisis Tahapan pembentukan sistem pakar

Tabel 3. Hasil Analisis metode sistem pakar

\begin{tabular}{|c|c|}
\hline Tahapan & Hasil \\
\hline 1. Identifikasi Masalah & $\begin{array}{l}\text { Aplikasi sistem pakar Certainty Factor berbasis web. Sistem berupa } \\
\text { tingkat ansietas dan solusi berupa terapi yang bisa dilakukan oleh } \\
\text { keluarga. }\end{array}$ \\
\hline $\begin{array}{l}\text { 2. Mencari Sumber } \\
\text { Pengetahuan }\end{array}$ & $\begin{array}{l}\text { Mendapatkan data dari pakar keperawatan jiwa Bapak. Ns Abdul } \\
\text { Gowi, M.Kep, Sp. Kep.J, buku asuhan keperawatan jiwa, buku } \\
\text { psikiatrik, jurnal certainty factor. }\end{array}$ \\
\hline 3. Akuisisi pengetahuan & $\begin{array}{l}\text { Jurnal penelitian bidang keperawatan menjelaskan Terdapat } 8 \text { gejala } \\
\text { ansietas, terdapat } 5 \text { faktor ansietas dan } 3 \text { kriteria }\end{array}$ \\
\hline 4. Representasi pengetahuan & $\begin{array}{l}\text { Merepresentasikan basis pengetahuan kedalam Decision Tree,Soal } \\
\text { Cerita, Case Study. }\end{array}$ \\
\hline 5. Mesin Inferensi & $\begin{array}{l}\text { Mesin inferensi yang digunakan adalah Certainty Factor, memiliki } 5 \\
\text { tahapan meliputi: } \\
\text { 1. Tentukan rule. } \\
\text { 2. Pisahkan multiple rule menjadi single rule. } \\
\text { 3. Hitung nilai CF pakar dengan nilai mb dan } \mathrm{md} \text {. } \\
\text { 4. Hitung nilai CF(H,E) setiap rule. } \\
\text { 5. Hitung nilai } \mathrm{CF} \text { gabungan. }\end{array}$ \\
\hline 6. Implementasi & $\begin{array}{l}\text { Mengimplementasikan sistem menggunakan Object Oriented } \\
\text { Programming Analysis dan Object Oriented Design. }\end{array}$ \\
\hline 7. Pengujian & Pengujian disajikan kedalam bentuk blackbox dan whitebox. \\
\hline 8. Keputusan & $\begin{array}{l}\text { Sistem pakar gangguan ansietas perpisahan masa kanak dan } \\
\text { remaja dapat mewakili human expert. }\end{array}$ \\
\hline
\end{tabular}

\section{Hasil Representasi Pengetahuan}

1. Decision Tree

Hasil Representasi pengetahuan untuk Decision Tree menghasilkan 18 rule.

Deskripsi pohon keputusan : 


\section{ILKOM Jurnal Ilmiah Volume 9 Nomor 1 April 2017}

1 : Apakah sedang dan pernah mengalami penyakit kronis?

2 : Apakah pernah sakit dan dirawat di rumah sakit?

3 : Tidak teridentifikasi gangguan ansietas

4 : Apakah pelayanan di rumah sakit buruk ?

5 : Apakah anak anda pernah mengalami perpisahan dengan orang tua atau orang terdekat dengan anda?

6 : Apakah berusia antara 6 - 10 Tahun ?

7 : Apakah berusia antara $11-13$ Tahun ?

8 :Apakah berusia antara $14-18$ Tahun ?

9 :Apakah berjenis kelamin anda perempuan?

10 Manakah gejala yang sesuai dengan kondisi anda?

A1 : Ansietas ringan (hasil skor 8-15)

A2 : Ansietas sedang (hasil skor 16-24)

A3 : Ansietas Berat (hasil skor 25-32)

TC : Tidak ada ansietas/kecemasan

\section{Case Study}



Gambar 4. Pohon Keputusan gangguan ansietas

Tabel 5. Case Study

\begin{tabular}{|c|c|c|c|c|c|c|c|c|c|c|c|c|}
\hline \multirow{3}{*}{ Rule } & \multicolumn{12}{|c|}{ FAKTOR dan GEJALA KECEMASAN } \\
\hline & \multirow{2}{*}{$\begin{array}{c}\text { Status Kesehatan } \\
\text { Kronis }\end{array}$} & \multirow{2}{*}{$\begin{array}{c}\text { Pengalaman } \\
\text { Rawat }\end{array}$} & \multirow{2}{*}{$\begin{array}{c}\begin{array}{c}\text { Sistem } \\
\text { Pendukung }\end{array} \\
\text { Buruk }\end{array}$} & \multicolumn{3}{|c|}{ Usia (Tahun) } & \multirow{2}{*}{$\begin{array}{c}\text { Stressor } \\
\text { Pernah pisah }\end{array}$} & \multirow{2}{*}{ JK } & \multicolumn{3}{|c|}{ Skor Gejala } & \multirow{2}{*}{ Tingkat Kecemasan } \\
\hline & & & & $6-10$ & 11-13 & $14-18$ & & & $25-32$ & $16-24$ & 8-15 & \\
\hline 1 & $\mathrm{v}$ & $\mathrm{v}$ & $\mathrm{v}$ & $\mathrm{v}$ & & & $\mathrm{v}$ & $P$ & $\mathrm{v}$ & & & A3 \\
\hline 2 & $\mathrm{v}$ & $\mathrm{v}$ & $\mathrm{v}$ & $\mathrm{v}$ & & & $\mathrm{v}$ & $\mathrm{P}$ & & $\mathrm{v}$ & & $\mathrm{A} 2$ \\
\hline 3 & $\mathrm{v}$ & $\mathrm{v}$ & $\mathrm{v}$ & $\mathrm{v}$ & & & $\mathrm{v}$ & $\mathrm{P}$ & & & $\mathrm{v}$ & A1 \\
\hline 4 & $\mathrm{v}$ & $\mathrm{v}$ & $\mathrm{v}$ & $\mathrm{v}$ & & & $\mathrm{v}$ & L & $\mathrm{v}$ & & & А3 \\
\hline 5 & $\mathrm{v}$ & $\mathrm{v}$ & $\mathrm{v}$ & $\mathrm{v}$ & & & $\mathrm{v}$ & L & & $\mathrm{v}$ & & A2 \\
\hline 6 & $\mathrm{v}$ & $\mathrm{v}$ & $\mathrm{v}$ & $\mathrm{v}$ & & & $\mathrm{v}$ & L & & & $\mathrm{v}$ & A1 \\
\hline 7 & $\mathrm{v}$ & $\mathrm{v}$ & $\mathrm{v}$ & & $\mathrm{v}$ & & $\mathrm{v}$ & $\mathrm{P}$ & $\mathrm{v}$ & & & A3 \\
\hline 8 & $\mathrm{v}$ & $\mathrm{v}$ & $\mathrm{v}$ & & $\mathrm{v}$ & & $\mathrm{v}$ & $\mathrm{P}$ & & $\mathrm{v}$ & & A2 2 \\
\hline 9 & $\mathrm{v}$ & $\mathrm{v}$ & $\mathrm{v}$ & & $\mathrm{v}$ & & $\mathrm{v}$ & $\mathrm{p}$ & & & $\mathrm{v}$ & A1 \\
\hline 10 & $\mathrm{v}$ & $\mathrm{v}$ & $\mathrm{v}$ & & $\mathrm{v}$ & & $\mathrm{v}$ & L & $\mathrm{v}$ & & & А3 \\
\hline 11 & $\mathrm{v}$ & $\mathrm{v}$ & $\mathrm{v}$ & & $\mathrm{v}$ & & $\mathrm{v}$ & $\mathrm{L}$ & & $\mathrm{v}$ & & $\mathrm{A} 2$ \\
\hline 12 & $\mathrm{v}$ & $\mathrm{v}$ & $\mathrm{v}$ & & $\mathrm{v}$ & & $\mathrm{v}$ & L & & & $\mathrm{v}$ & A1 \\
\hline 13 & $\mathrm{v}$ & $\mathrm{v}$ & $\mathrm{v}$ & & & $\mathrm{v}$ & $\mathrm{v}$ & $\mathrm{p}$ & $\mathrm{v}$ & & & A3 \\
\hline 14 & $\mathrm{v}$ & $\mathrm{v}$ & $\mathrm{v}$ & & & $\mathrm{v}$ & $\mathrm{v}$ & $\mathrm{P}$ & & $\mathrm{v}$ & & $\mathrm{A} 2$ \\
\hline 15 & $\mathrm{v}$ & $\mathrm{v}$ & $\mathrm{v}$ & & & $\mathrm{v}$ & $\mathrm{v}$ & $\mathrm{P}$ & & & $\mathrm{v}$ & A1 \\
\hline 16 & $\mathrm{v}$ & $\mathrm{v}$ & $\mathrm{v}$ & & & $\mathrm{v}$ & $\mathrm{v}$ & L & $\mathrm{v}$ & & & A3 \\
\hline 17 & $\mathrm{v}$ & $\mathrm{v}$ & $\mathrm{v}$ & & & $\mathrm{v}$ & $\mathrm{v}$ & L & & $\mathrm{v}$ & & A2 \\
\hline 18 & $\mathrm{v}$ & $\mathrm{v}$ & $\mathrm{v}$ & & & $\mathrm{v}$ & $\mathrm{v}$ & $\mathrm{L}$ & & & $\mathrm{v}$ & A1 \\
\hline
\end{tabular}

\section{Soal Cerita Untuk Ansietas Berat}

Seorang anak perempuan bernama $A$ berusia 10 tahun pernah mengalami perpisahan dengan orang tua nya dikarenakan kecelakaan. Sejak saat itu A tinggal dan dianggap sebagai anak kandung oleh bibi nya. Setelah mengalami kejadian itu tingkah laku A menjadi tidak mau sendiri, tidak mau ditinggalkan pergi, tidak mau sekolah kalau tidak diantar dan ditemani, tidak mau tidur sendiri dan sering bercerita tentang mimpi buruk dan ketika ditinggalkan sering mengeluh sakit kepala, mual dan muntah (Setelah dihitung skor gejala adalah 30). Karena keadaan tersebut A jatuh sakit terkena penyakit diare dan harus dirawat, setelah masuk rumah sakit ternyata pelayanan di rumah sakit tidak begitu baik. 
ILKOM Jurnal Ilmiah Volume 9 Nomor 1 April 2017

Mesin inferensi Certainty Factor

Tabel 4. Nilai Certainty Factor untuk pengguna

\begin{tabular}{clc}
\hline No & Deskripsi & Nilai \\
\hline 1 & Sangat yakin & 1 \\
2 & Yakin & 0.8 \\
3 & Cukup yakin & 0.6 \\
4 & Mungkin & 0.4 \\
5 & Tidak & 0
\end{tabular}

Tabel 5. Nilai Certainty Factor untuk pakar

Contoh perhitungan certainty factor untuk rule 1

1. Tentukan rule

IF sedang dan pernah mengalami penyakit kronis

and pernah sakit dan dirawat di rumah sakit

and pelayanan rumah sakit buruk

and pernah mengalami perpisahan

and usia 6-10 tahun

and jenis kelamin perempuan

and Gejala yang sesuai (skor gejala 25-32)

then ansietas berat

2. Pisahkan multiple rule jadi single rule

RULE 1.1 (IF sedang dan pernah mengalami penyakit kronis THEN Ansietas berat)

RULE 1.2 (IF pernah sakit dan dirawat di rumah sakit THEN Ansietas berat)

RULE 1.3 (IF pelayanan rumah sakit buruk THEN Ansietas berat)

RULE 1.4 (IF pernah mengalami perpisahan THEN Ansietas berat)

RULE 1.5 (IF usia 6-10 tahun THEN Ansietas berat)

RULE 1.6 (IF jenis kelamin perempuan THEN Ansietas berat)

RULE 1.7 (IF Gejala yang sesuai (skor gejala 25-32) THEN Ansietas berat)

3. Hitung nilai CF Pakar dengan persamaan

$C F[h, e]=M B[h, e]-M D[h, e]$

CF Pakar sedang dan pernah mengalami

penyakit kronis $=0.6-0.1=0.5$

CF Pakar pernah sakit dan dirawat di rumah sakit $=0.6-0.1=0.5$

CF Pakar pelayanan rumah sakit buruk $=0.6-0.1=0.5$

CF Pakar pernah mengalami perpisahan $=0.8-0.1=0.7$

CF Pakar usia 6-10 tahun $=0.6-0.1=0.5$

CF Pakar Jenis kelamin perempuan $=0.6-0.1=0.5$

CF Pakar Gejala yang sesuai (skor gejala 25-32) $=0.8-0.1=0.7$

4. Hitung nilai $\mathrm{CF}$ dengan persamaan $\mathrm{CF}(\mathrm{H}, \mathrm{E})=\mathrm{CF}$ (user) ${ }^{*} \mathrm{CF}$ (pakar)

CF $1.1=1 * 0.5=0.5$

$\mathrm{CF} 1.2=1 * 0.5=0.5$

CF $1.3=1 * 0.5=0.5$

CF $1.4=1 * 0.7=0.7$

CF $1.5=1 * 0.5=0.5$

CF $1.6=1 * 0=0$

CF $1.7=1 * 0.7=0.7$

5. Hitung nilai CF gabungan dengan persamaan CF COMBINE(CF1,CF2) $=$ CF1 + CF2*(1-CF1)

$(\mathrm{CF} 1, \mathrm{CF} 2)=0.5+0.5^{*}(1-0.5)=0.75$ old

(Cfold, CF3 $)=0.75+0.5^{*}(1-0.75)=0.875$ old

(Cfold,CF4) $=0.875+0.7^{*}(1-0.875)=0.9625$ old

(Cfold, CF5 $)=0.9625+0.5^{*}(1-0.9625)=0.98125$ old

(Cfold,CF6 $)=0.98125+0 *(1-0.98125)=0.98125$ old

(Cfold,CF7) $=0.98125+0.7^{*}(1-0.98125)=0.994375$

Presentasi Kepercayaan $=0.994375 * 100 \%=99.44 \%$ Ansietas berat $/$ Kecemasan berat

Tabel hasil nilai certainty factor untuk rule 1-8 dibawah ini menunjukkan hasil untuk pilihan jawaban YA (Sangat Yakin) yang bernilai 1. 
ILKOM Jurnal IImiah Volume 9 Nomor 1 April 2017

Tabel 6. Hasil Nilai certainty factor untuk rule 1-6

\begin{tabular}{|c|c|c|c|c|c|c|c|c|c|}
\hline Rule & Tingkat ansietas & Pengalaman & $\begin{array}{c}\text { Sistem } \\
\text { pendukung }\end{array}$ & $\begin{array}{c}\text { Status } \\
\text { kesehatan }\end{array}$ & Usia (Tahun) & stressor & JK & Skor gejala & Nilai certainty factor \\
\hline 1 & Ansietas Berat & Rawat & Buruk & Kronis & 6-10 & Pernah Pisah & $\mathrm{L}$ & $25-32$ & $99.44 \%$ \\
\hline 2 & Ansietas Sedang & Rawat & Buruk & Kronis & $6-10$ & Pernah Pisah & L & $16-24$ & $99.44 \%$ \\
\hline 3 & Ansietas Ringan & Rawat & Buruk & Kronis & $6-10$ & Pernah Pisah & L & 8-15 & $99.44 \%$ \\
\hline 4 & Ansietas Berat & Rawat & Buruk & Kronis & $6-10$ & Pernah Pisah & $\mathbf{P}$ & $25-32$ & $99.72 \%$ \\
\hline 5 & Ansietas Sedang & Rawat & Buruk & Kronis & $6-10$ & Pernah Pisah & $\mathbf{P}$ & $16-24$ & $99.72 \%$ \\
\hline 6 & Ansietas Ringan & Rawat & Buruk & Kronis & 6-10 & Pernah Pisah & $\mathbf{P}$ & 8-15 & $99.72 \%$ \\
\hline 7 & Ansietas Berat & Rawat & Buruk & Kronis & $11-13$ & Pernah Pisah & $\mathrm{L}$ & $25-32$ & $99.44 \%$ \\
\hline 8 & Ansietas Sedang & Rawat & Buruk & Kronis & $11-13$ & Pernah Pisah & $\mathrm{L}$ & $16-24$ & $99.44 \%$ \\
\hline 9 & Ansietas Ringan & Rawat & Buruk & Kronis & $11-13$ & Pernah Pisah & $\mathrm{L}$ & $8-15$ & $99.44 \%$ \\
\hline 10 & Ansietas Berat & Rawat & Buruk & Kronis & $11-13$ & Pernah Pisah & $P$ & $25-32$ & $99.72 \%$ \\
\hline 11 & Ansietas Sedang & Rawat & Buruk & Kronis & $11-13$ & Pernah Pisah & $\mathrm{P}$ & $16-24$ & $99.72 \%$ \\
\hline 12 & Ansietas Ringan & Rawat & Buruk & Kronis & $11-13$ & Pernah Pisah & $\mathbf{P}$ & 8-15 & $99.72 \%$ \\
\hline 13 & Ansietas Berat & Rawat & Buruk & Kronis & $14-18$ & Pernah Pisah & $\mathrm{L}$ & $25-32$ & $99.44 \%$ \\
\hline 14 & Ansietas Sedang & Rawat & Buruk & Kronis & $14-18$ & Pernah Pisah & L & $16-24$ & $99.44 \%$ \\
\hline 15 & Ansietas Ringan & Rawat & Buruk & Kronis & $14-18$ & Pernah Pisah & $\mathrm{L}$ & $8-15$ & $99.44 \%$ \\
\hline 16 & Ansietas Berat & Rawat & Buruk & Kronis & $14-18$ & Pernah Pisah & $\mathrm{P}$ & $25-32$ & $99.72 \%$ \\
\hline 17 & Ansietas Sedang & Rawat & Buruk & Kronis & $14-18$ & Pernah Pisah & $\mathrm{P}$ & $16-24$ & $99.72 \%$ \\
\hline 18 & Ansietas Ringan & Rawat & Buruk & Kronis & $14-18$ & Pernah Pisah & $\mathrm{P}$ & $8-15$ & $99.72 \%$ \\
\hline
\end{tabular}

2. Analisis Sistem

System Activities

a. Actor Description: Aktor pada aplikasi ini terdiri dari dua aktor yang disebut pakar dan pengguna.

b. Use Case Diagram ditunjukkan pada gambar 5.

c. Skenario Use Case: Terdiri dari tujuh skenario yaitu pendaftaran, diagnosis, hasil diagnosis, Tanya jawab pakar, lihat rating, lihat rekapan.

d. Class Diagram ditunjukkan pada gambar 6 .

e. Object Interaction (Sequence Diagram): Terdiri dari tujuh sequence yaitu pendaftaran, diagnosis, hasil diagnosis, tanya jawab pakar, lihat rating, lihat rekapan, ditunjukkan pada gambar 7 mewakili salah satu dari beberapa Sequence Diagram yaitu Sequence Diagram diagnosis.

f. Object Behavior (Activity Diagram): Terdiri dari tujuh activity diagram yaitu pendaftaran, diagnosis, hasil diagnosis, tanya jawab pakar, lihat rating, lihat rekapan, ditunjukkan pada gambar 8 mewakili salah satu dari beberapa Activity Diagram yaitu Activity Diagram diagnosis.

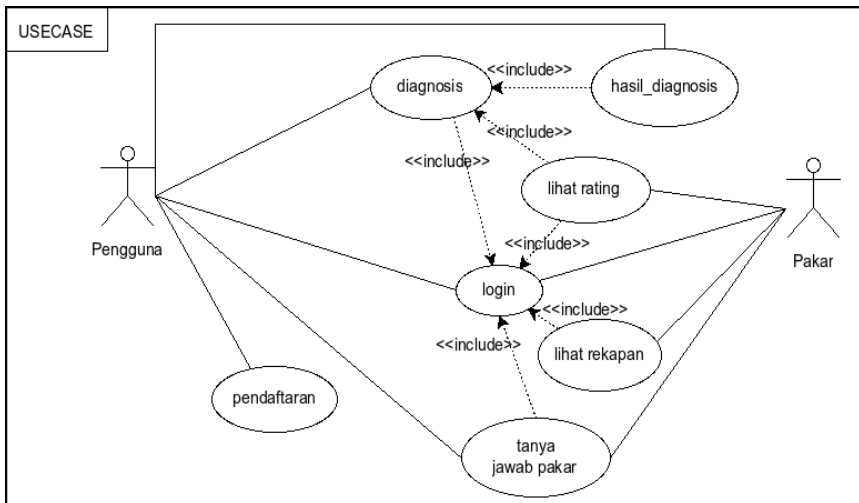

Gambar 5. Use Case Diagram

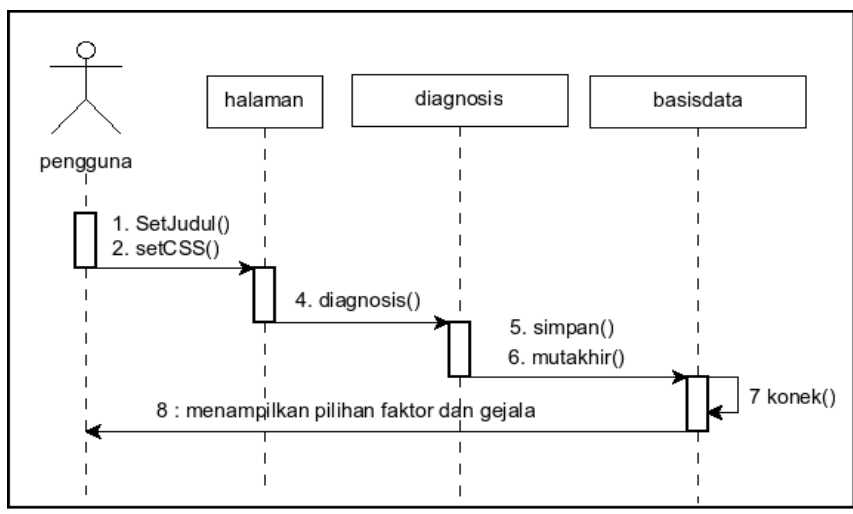

Gambar 7. Sequence Diagnosis

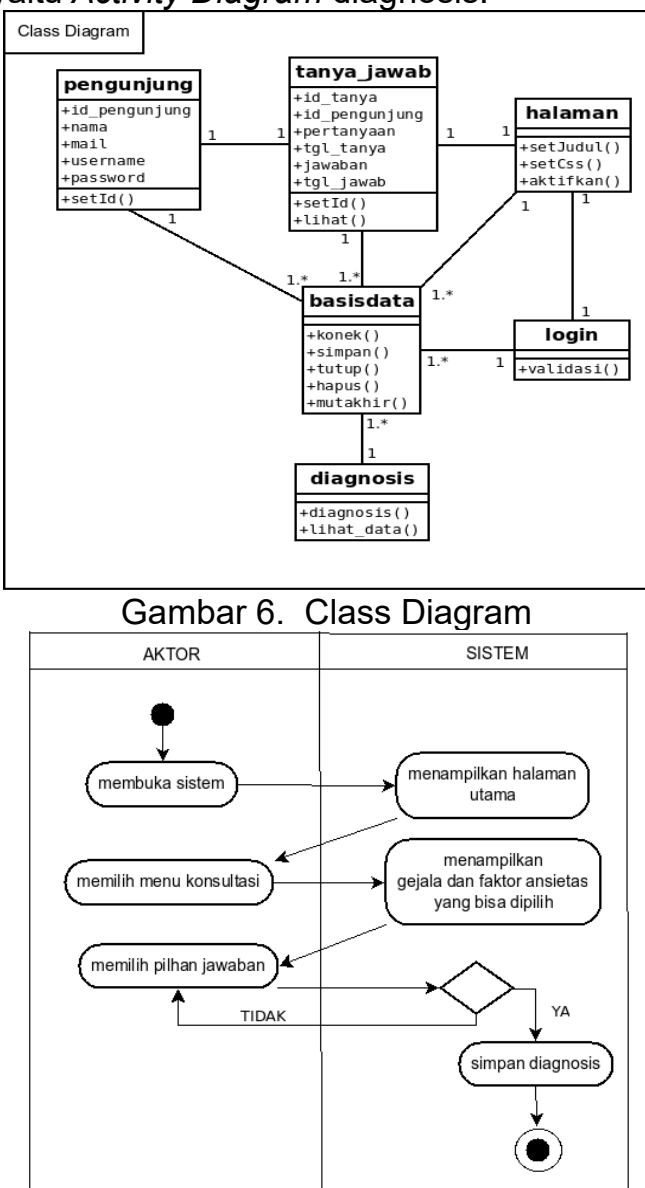

Gambar 8. Activity Diagnosis 
ILKOM Jurnal IImiah Volume 9 Nomor 1 April 2017

\subsection{Design Phase}

1. Desain Antarmuka.

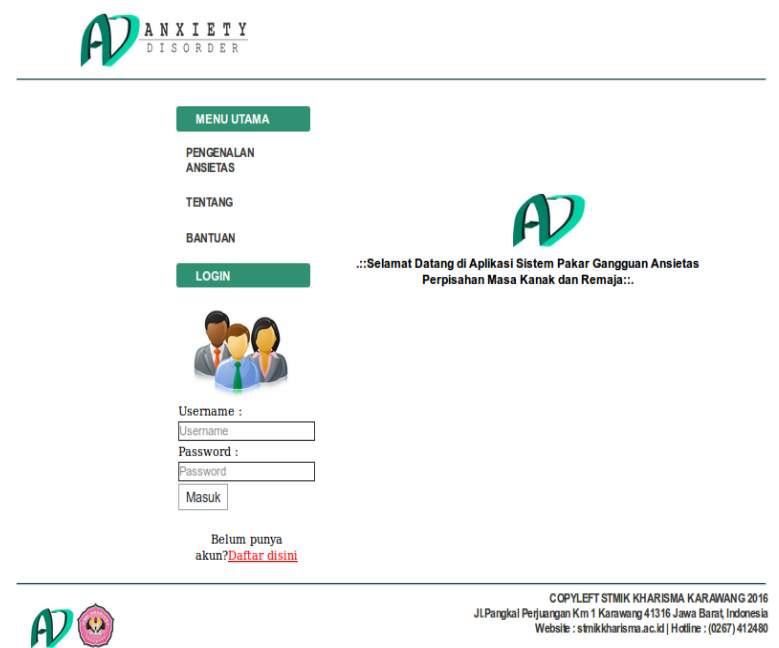

\section{Desain Database}

Gambar 9. Hasil Desain Tampilan Halaman Utama Pakar
a. Tabel gejala kecemasan
b. Tabel tanya jawab
c. Tabel Pengunjung
d. Tabel diagnosis
e. Tabel tampung gejala

f. Tabel terapi bermain

g. Tabel terapi keluarga

h. Tabel terapi progresif

I. Tabel terapi relaksasi

j. Tabel terapi perilaku

\subsection{Implementation Phase}

1. Instalasi Sistem

A. Instalasi Geany

B. Instalasi Apache

C. Instalasi MySQL

D. Instalasi phpMyAdmin

E. Instalasi Sistem pakar gangguan

ansietas perpisahan dalam localhost

2. Pelatihan Prosedural

Berisi tata cara penggunaan aplikasi untuk :
A. Pendaftaran
B. Diagnosis
C. Tanya jawab pakar

3. Pengujian Terhadap Sistem

a. Blackbox: Telah diujikan kepada pakar dan dua orang pengguna dengan hasil teruji. Untuk pengujian pakar sebanyak tujuh fungsi meliputi masuk halaman utama, pendaftaran, login, diagnosis, tanya jawab pakar, lihat rating, lihat rekapan sedangkan pengguna sebanyak lima dari tujuh fungsi.

b. Whitebox: Pengujian whitebox menggunakan source code simpan diagnosis.

1. Flowgraph simpan diagnosis

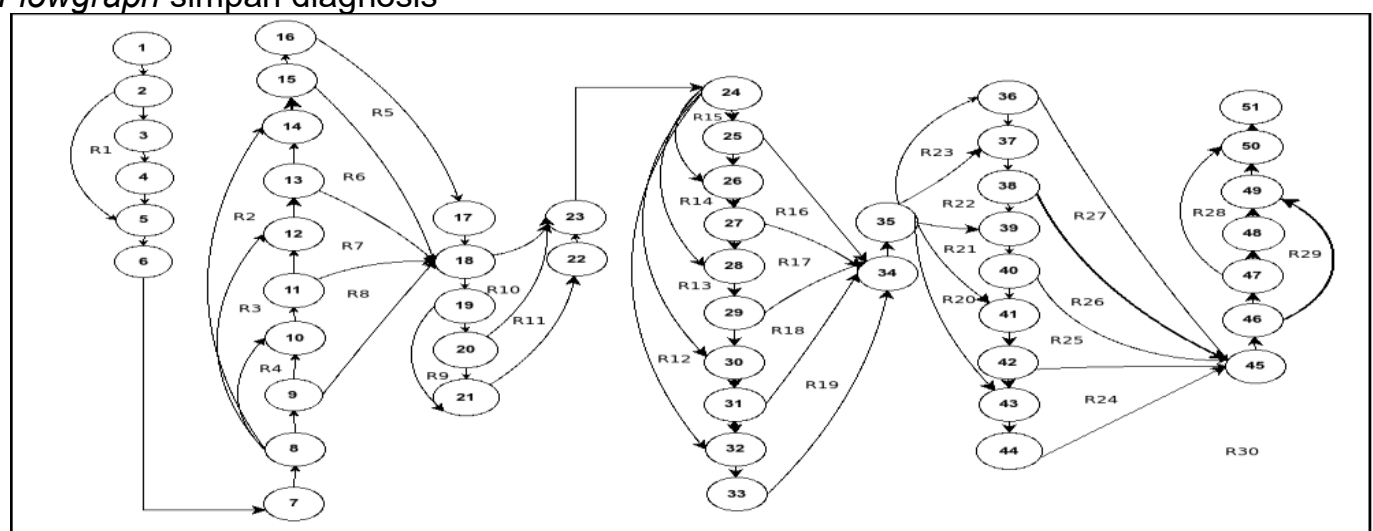

Gambar 10. Flowgraph simpan diagnosis 
ILKOM Jurnal IImiah Volume 9 Nomor 1 April 2017

2. Cyclomatic Complexity $\mathrm{V}(\mathrm{G})$

$\mathrm{V}(\mathrm{G}) \quad=30$

$=79-51-+2=30$

$\mathrm{V}(\mathrm{G}) \quad=\mathrm{E}-\mathrm{N}+2 \mathrm{~V}(\mathrm{G})$

$V(G) \quad=P+1$

\section{Kesimpulan}

Berdasarkan penelitian yang telah dilakukan dalam membangun aplikasi ini, maka dapat ditarik kesimpulan :

1. Dapat melakukan diagnosis gangguan ansietas perpisahan masa kanak dan remaja dengan keluaran sistem memiliki tingkatan keyakinan YA (bernilai 1) yaitu paling tinggi $99,72 \%$ dan paling rendah $99,44 \%$.

2. Dapat mengimplementasikan mesin inferensi Certainty Factor dan metode pengembangan sistem SDLC Waterfall.

\section{Daftar Pustaka}

[1] Marimin, 2009. Teori dan apilkasi sistem pakar dalam teknologi menajemen.Bogor: IPB Press.

[2] Hamid, Achir Yani S. 2009. Bunga Rampai Asuhan Keperawatan Kesehatan Jiwa. Jakarta: Penerbit Buku Kedokteran EGC.

[3] [Kemenkes]: Kementrian Kesehatan RepublikIndonesia (ID). 2007 Riset Kesehatan Dasar 2007.

[4] [Kemenkes]: Kementrian Kesehatan Republik Indonesia (ID). 2013. Riset Kesehatan Dasar 2013.

[5] Rakhmatika, Dewi. 2014. Skripsi: Hubungan Tingkat Kecemasan Perpisahan Dengan Orang Tua $T$ erhadap Motivasi Belajar Santri Di Pondok Pesantren Asshidiqiyah Kebun Jeruk Jakarta. Jakarta: UIN Syarif Hidayatullah Jakarta.

[6] Kusrini, 2008. Aplikasi Sistem Pakar. Yogyakarta: Penerbit ANDI.

[7] Giarratano.J.C \& Riley G, 1994. Expert system: Principles and Programming, 2nd edition, PWS Publishing Co. USA.

[8] Mujilahwati, Siti, 2014. Diagnosa Penyakit Tanaman Hias Menggunakan Metode Certainty Factor Berbasis Web. Universitas Islam Lamongan.

[9] Setyarini, eka, Putra, Darma dan Purnawan 2013. The Analysis of Comparison of Expert System of Diagnosing Dog Disease by Certainty Factor Method and Dempster-Shafer Method. Bali : Udayana University.

[10] Satzinger, John W, Jackson, Robert B, and Burd, Stephen D. 2010, Systems Analysis and Design in a Changing World, Fifth Edition. Course Technology, Boston. 